\title{
The Belief System of Christianity and Tribal Religion in Hukurila's Ritual
}

\author{
Karisma Erikson Tarigan ${ }^{1} \square$ and Margaret Stevani ${ }^{2}$ \\ ${ }^{12}$ Fakultas Pendidikan Bahasa Inggris, Universitas Katolik Santo Thomas Sumatera Utara, Indonesia \\ $\square$ Corresponding Author: Karisma Erikson Tarigan, E-mail: erick_tarigan2006@yahoo.com
}

\begin{abstract}
ARTICLE INFO
Received: 11 September 2021

Accepted: 16 October 2021

Published: 21 October 2021

DOI: $10.32996 /$ ijcrs.2021.1.1.4

\section{KEYWORDS}

Christianity,

Tribal Religion,

The Washing Country,

Hukurila's Ritual

\section{ABSTRACT}

This study aimed to describe the belief system between Christianity and Tribal religion in Hukurila's ritual. The data descriptions were based on the Washing Country as a physical act of traditional rituals and combined with their beliefs as Christians. The object of this research was the Hukurila community, South Leitimur District, Ambon City, especially in the practice of washing the country ritual. This study used hermeneutic analysis as the text result was positioned as an ontology fact. Furthermore, the text was an ontological fact by objectifying its structure to look at forms in community values. The results showed that the Washing country not only taught about the role of ancestors in the history of the children of the Hukurila country but also revealed critical reasoning that highlighted the role of humans in nature conservation. The Washing Country promoted environmental preservation as a part of social piety.
\end{abstract}

\section{Introduction}

Human knowledge allows humans to realize their desire to know everything, even to know the meaning of their existence in the world. This gives birth to human knowledge about themselves or about the world they face. Human knowledge makes itself not an independent being. It exists in a dialectical relationship between itself and society and culture. Humans always create a number of values for society and he becomes an integral part of society. Society as a result of human social processes creates an identity for humans that can be recognized in the cultural values of society.

In one region of Indonesia which is called Maluku, one form of dialectic that often occurs is the dialectic between tribal religion and Christianity. Tribal religion, in the perspective of the Maluku people, is referred to as adat. Adat becomes a value maker for the enrichment of the identity of the country's children. Adat becomes a very close bond to embrace every child of the country wherever he is. Adat is seen as a divine guide from the world of the ancestors who have a lineage with the divine world (the supernatural world). Here, each tribe claims to be part of the genealogical line of its ancestors, so that customary symbols, customary behavior, and so on are used as correct doctrines (Watloly: 2005). Because it is very genealogical, the solidarity that is formed is also emotive and mechanistic in terms of ethnicity.

The dialectic between tribal religion and Christianity in Maluku, according to Steve Gaspersz (2007) in his research, exists in two perspectives, namely the sociohistorical and the theological perspectives. Sociohistorically, in the history of Maluku, "colonialization" and "neo-colonialization" in the islands Maluku (especially in Central Maluku, which is the center of trade and politics) creates many cultural conflicts in people's lives. Likewise, through historical records, it has been known that the entry of missionary institutions to Maluku introjected various theological views formed by Western culture. Especially regarding the essence of local culture and the position of Christian theology at that time on adat. The mission's theological view of adat at that time was bipolar. At one pole, they try to understand community customs, but at the other pole, they are trapped in pejorative presumptions. For them, Christianity from the West is a form of modern culture that is more "good", "true", "high" and "civilized" than the local culture in Maluku. This arrogance and triumfalistic attitude are shown by looking down on every expression of local culture, even getting rid of the belief system of the local community because it is considered a manifestation of evil power. This is one of the

Copyright: (c) 2021 the Author(s). This article is an open access article distributed under the terms and conditions of the Creative Commons Attribution (CC-BY) 4.0 license (https://creativecommons.org/licenses/by/4.0/). Published by Al-Kindi Centre for Research and Development, London, United Kingdom. 
implications of the positivistic theological view which was strongly influenced by the spirit of the Enlightenment which deconstructed the world view of European society at that time.

Theologically, Gaspersz revealed that almost all theological debates that arose around the relationship between "gospel" and "custom" in the history of Christianity in Maluku were caused by the limited theological and anthropological insights of Western evangelists and local evangelists in building an open Christian perspective. This is also further strengthened by the primordial exclusivity of traditional leaders whose reasoning structure is patterned in the construction of identity as an "elite group" created by the colonial authorities in order to safeguard all their political and economic interests in the controlled areas.

The evangelists at that time, according to Gaspersz, were strongly influenced by the colonial era's pietic theology, which saw culture/customs as the work of sinful humans and therefore carnal and "pagan". These "pagans" must be converted and introduced to the gospel of Christ. Unfortunately, the essence of the Gospel of Christ is generalized with the "packaging" of Western culture that is brought in, so that the message of the Gospel is distorted in meaning. As a result, everything related to local cultural expressions is always associated with the "dark world". In fact, there are many stories and historical reflections in the Bible that indicate how the encounter with God took place in the local cultural order of the people at that time.

For Gaspersz, such a theological attitude has resulted in Maluku culture never being the theological basis for understanding God's love which has given him the opportunity to worship Him as a Moluccan with a Moluccan culture. That is, the Moluccans worship God in the integrity of their own human existence. In Maluku culture, there are many aspects that can actually be used as a medium to raise local values into contextual theological discourse.

Contextualization means the activity or process of combining the message of the Bible with the conditions (context), so that contextualization is not enough just to study the Bible (although this is absolute) but is also very important to understand the context. (Drewes and Mojau: 2003). The Bible is indeed a reference for Christians in carrying out their actions and lives, but it is not enough just to read and study it. How the contents of the Bible are put into practice and used as a guide and adapted to what happens in situations and conditions experienced by the community or community is more important. If you just do what is written in the Bible without adapting it or contextualizing it to a particular situation, theology becomes empty and homeless theology. Therefore, if each society or community has a different history and culture, it means that the theological views of each society or community will also be different from other communities. So the center of theology is the history and culture in which humans exist and become part of a community.

Contextual can be understood as dialogue or, according to David Tracy as quoted by Stephen B. Bevans contextual is a reciprocal critical dialogue between past experiences and present experiences. Theology is letting current experience be measured and judged by classical wisdom. (Bevans: 2010). The meeting of these two conditions makes theology appropriate to be carried out by individuals and communities according to cultural and historical backgrounds. The orientation to include or introduce theology means to consciously give or receive counsel from past and present saints.

Theology, basically, must be able to be the answer to the problems that occur factually, so that theology is not trapped in abstract discussions about concepts that cannot be proven. Theology must move in all directions, meaning that it is not only limited to vertical movements but also horizontal movements. Theology is also practiced for others, including culture, and not only to talk to God.

Culture in Maluku society is always a process of the interpenetration of two or more cultural elements. Anton Bakker (1995) discusses the word interpenetration with the word "compensation" which means breaking through each other and uniting themselves so that it is a whole world. Bakker's statement about interpenetration implies that empirically social systems are considered as open systems and influence each other creatively.

The process of interpenetration in culture in Maluku has shaped the cultural character of a heterogeneous society. Likewise, with the ritual of washing the land in Hukurila, Ambon Island. The Washing Country ritual is not only a physical act of cleaning the village but also a special struggle that is unique between Christianity and Tribal religion in the dialectical process. They (Hukurila people) are creatures who always seek meaning from their environment through traditional rituals and combined with their beliefs as Christians. That is, on the one hand, Christianity takes the opposite position when it seems that the traditions of society are not in accordance with Christian dogma and are considered a form of paganism. But on the other hand, Christianity expresses full support when it seems that these traditions have a positive impact on the evangelism process so that new values often emerge in community traditions as a form of Christian influence. 
The problem in this paper is how the process of interpenetration between Christianity and tribal religion in the Washing Country ritual in Hukurila. To answer this problem, the author will present the process of washing the country's traditional ritual itself and how the interpenetration process is carried out with Christianity as a form of dialectical struggle with tribal religion. However, the author will also state the value that was born as a result of the interpenetration process. This was conveyed as a goal to provide a complete picture of the process of washing the country in Hukurila and the new pattern that was born in the ritual as a form of interpretation of the Hukurila community on its socio-cultural reality.

This writing is expected to provide benefits for the development of theological contextualization through cultural elements in society. That is, the church (Christianity) is faced with cultural challenges. On the one hand, he was built and grew from the people's spiritual appreciation of the work of Christ which he knew through a long history of evangelism. However, on the other hand, the primordial culture in which he grew up and built his faith was also challenged by the pressure of a new culture as a consequence of changing times. These two challenges must be faced at the same time.

As a result, ethically the church is able to see cultural values as an effort to maintain its existence. So that a church that lives in dialectics with local culture is a church that really wants to open its eyes and ears and be involved in human struggles. In this context, the church continues to be an embodiment of God's love that moves in all directions and encourages us to think and act without fear of risking the loss of self-esteem.

\section{Methodology}

The data analysis in this study used the hermeneutic method, which is related to the overall meaning of a text and the interpretation of its parts. Data analysis using the hermeneutic method referred to here is Paul Ricoeur's hermeneutics, namely the operation of understanding in relation to text interpretation (Acep Iwan Saidi: 2008). Texts are always related to society, be they works of art, traditions, or ideas that live in society. The object of this research is the Hukurila community, South Leitimur District, Ambon City, especially in the practice of washing the country ritual.

Saidi also mentions that meaning or temporal interpretation (temporary because of the context) is always mediated by a series of markers and, of course, by the text. Thus, the task of hermeneutics does not look for similarities between the intentions of the messenger and the interpreter. The task of hermeneutics is to interpret meanings and messages as objectively as possible according to what the text wants. The text itself, of course, is not limited to autonomous facts written or painted (visual) but is always related to the context (Saidi: 2008).

The workings of Ricoeur's Hermeneutic method and approach are as follows: at first, the text is placed as an object under study as well as an autonomous subject or center. The text is positioned as an ontology fact. Furthermore, the text as an ontological fact is understood by objectifying its structure. Here structural analysis occupies an important position. In the next stage, understanding is expanded when it enters the symbolization layer. This happens because, here, the interpretation has exceeded the limits of the structure. Symbolic codes that are interpreted, of course, require things that are referential regarding the factors related to them. The symbolic code emitted by the text and associated with various problems outside itself requires other disciplines to complete the interpretation. Finally, the end of the process is the discovery of meaning or message.

\section{Results and Discussion}

\subsection{State Washing Ritual in Hukurila}

The ritual of washing the state in Hukurila is inseparable from the history of the formation of the seventh state or Hukurila today, due to various events encountered during the time of travel/migration of the Hukurila community. The various difficulties encountered during the journey gave them an understanding that the occupied territory should be cleaned not only of the environment but as a whole including asking for blessings from the ancestors for new territory. The bitter experiences experienced in Batu Bulan (the state long before Hukurila today) such as earthquakes, disease outbreaks, the distance of water sources in their belief system are inherent from the disapproval of the place by the ancestors.

The current ritual process of washing the state in Hukurila begins with a meeting of three hearthstones (State Government, Education element, and Church element) on 13 pm, followed by sprinkling water in all four corners of the country by the King (designation for village head) Hukurila. These four corners are not the boundaries of the state territory or symbolism of the four corners of the wind, but rather addressed to the teun (customary territory) of the state of Hukurila. On the 14th in the morning, a group of saniri negeri (village council) led by the head of Soa (traditional leader) Peimahu as a traditional priest, headed to the old land to perform the ritual of summoning the spirits of the ancestors, in the center of the old country, to descend with them to Hukurila in the process of a state cleansing ceremony. 
The sound of tupu (a wind instrument made of shells) accompanies the gallant steps of the country's saniri to pick up their ancestors. Around 6 am on the 14th. They returned to Hukurila which the head of Soa Moni had greeted with ina mata mothers (married mothers) in gandong cloth (long white cloth) to the village hall. In the understanding of the Hukurila community, those wrapped in gandong cloth are not only the state saniri entourage but also the ancestors. In their belief, they wanted to show their ancestors that this was the land that their ancestors had inherited from them. At the village hall, the rest of the community was waiting along with their thanksgiving offerings to be handed over to the king and then the king would hand over the offerings to the pastor in the church. From the village hall, a group of state saniri with the king and the people went to the church to perform Christian worship.

From the church, they went straight to Batu Teun (the center of the country). Here is told the history of the might of the ancestors, and the legacy of the values of the tradition of washing the country. Next, they headed to the state memorial stone. This stone is a reminder of the presence of the ancestors in the land of Hukurila in their diaspora from the island of Seram. On this stone, kings, priests, state saniri, and some new housewives symbolize state cleansing in the form of devotional work. This devotional work process is then carried out until December 16 with the division of the community that has been arranged in advance in locations that have been determined such as village halls, churches, highways, springs, cemeteries, and so on.

The culmination of a series of national washing traditions is carried out on the night of December 16, after the spirits of the ancestors are returned to the old country. In the past, the peak of the celebration of the washing of the country tradition ended with a meal together and a state party. But now the peak of the celebration ends with a national Christmas celebration.

Their reason is that by celebrating Christmas, people will avoid attitudes that can cause chaos in society. During the process of washing the country, the daily activities of the community were abolished because everything was focused on the tradition of washing the country.

\subsection{Tribes in the Ritual of Washing}

\subsubsection{Clash of Christianity with Tribal Religion}

The encounter between Christianity and tribal religion in the context of the Hukurila community did not run smoothly. There was a clash between the two, especially in the world view, including in the washing ceremony of the country. Christianity which was more influenced by Europeans at that time saw them as a "barbarian" nation, which tended to use violence and still existed in the practice of "idol worship".

This assumption also influences their views and attitudes towards all practices and values that have long been embedded in the tribal belief system of the Hukurila community. For them (Christian evangelists at that time) everything related to tribal practices had to be removed. God in Jesus Christ is the center of all human life; thus all belief orientations must be centered on what is taught in Christianity. Outside of that teaching, everything is considered a form of disbelief and because of that it is strongly opposed and even tends to be destroyed.

It is different from the Hukurila people who base their ideology about the world with myths and fragments of past stories as part of the community's collective memory. This way of thinking indicates that their belief system shows the unity of the knowledge system as a tribal community. This is accompanied by an attitude of mutual responsibility and togetherness in seeing the close relationship between tribal religious elites and the community. That is, there is no attitude of dropping or destroying one another in totality as a tribal community.

The differences in world views above also affect the washing tradition of the country. The cultural clash between Christianity and European style versus tribal religion in Hukurila. The pattern of washing the country that is happening today is different from the pattern of washing the country at the beginning (1902), especially regarding the ritual aspect. In the beginning, the biggest role was in adat institutions, using all of their traditional rituals that reflected their belief in their ancestors as the shapers and guardians of the country. They learn from the history of the past when the migration of these community groups occurred. For them, something is missing if they don't include their ancestors to build a new settlement. Therefore, in the implementation of washing the land, it is necessary to ask for the presence of the ancestors to together with them prepare the new settlements they will inhabit. The great service of the ancestors who have formed the Hukurila community is what they really value. Their world view states that it is the blessing of their ancestors that can bring them safety when they settle in a new area to avoid all calamities. Thus, in this initial process, the church was not involved in the whole series of washing ceremonies.

The church agrees with the relocation of the Hukurila community from Batu Bulan. But the church has openly expressed its disapproval of the ritual practices carried out in the process of washing the land. For the church at that time, their actions reflected idolatry and it was a form of pagan practice. It is not the ancestors who guarantee their salvation, but Christ who guarantees their 
salvation. Due to this difference of opinion, only a small part of the Hukurila community migrated to new settlements. Institutions of the church and some other communities followed later in January 1903. This was marked when the inauguration of a new Christian country on January 23, 1903, by the King and Pastor at that time, then the community was gathered as a whole.

\subsubsection{Knitting together Christianity and Tribal Religion}

Until 1933, the washing ceremony was only performed once when the Hukurila people migrated from Batu Bulan. This is because church institutions and customary institutions clash in their different understanding patterns of worldviews. In response to these conditions, efforts were made to "reconcile" the church and customs. Markus Tupan, the head of Soa Topea Peimahu who was also an elder of the church's religion at that time took the initiative to involve the church in all traditional processions in Hukurila. This is based on the understanding that the unity or totality of society does not only exist in one area, be it church or custom, but as a whole.

On that initiative, in the implementation of the washing of the land in 1933 the church was involved in it, with the procession being carried out as it is today. But that doesn't mean the cultural clash is over. Although some people have accepted the "presence" of the church in the entire washing procession, there are still some who still reject it. They think that customary territory should not be interfered with by the church. The two must be separated because they have different ideological foundations. As a result of the ongoing conflict, the washing of the land was not carried out in the following years. So it can be said that efforts to reconcile the church and customs have reached a dead end. But the positive thing is that there has been an openness and mutual acceptance between the church and adat.

Such a long conflict made the implementation of the washing of the country seem to be in suspended animation. The absence of washing the country for decades has become a burden for the head of the Topea Peimahu, Yakob Tupan. In a state of illness, in 1986 he called the descendants of Soa Topea Peimahu to explain the history of the Hukurila country in which there was a washing process. His explanation seemed to open their eyes to a tradition that had been buried like pearls at the bottom of the sea. He hoped that the implementation of the country's washing tradition would continue. In his view, a virtue that has been determined by the ancestors must be continued by the descendants of the Hukurila country. The whole stretch of the long history of children He described the country of Hukurila, including the "feud" between adat and the church. For days he told the whole history of the land of Hukurila, and how the procession of washing the country itself.

For such a valuable historical value, the state saniri took the initiative to carry out a state washing ceremony to become an annual tradition of the Hukurila community. This initiative received a positive response from the church at that time. The church even fully supports all traditional processions in the washing tradition of the land. No one questioned what was the ideological basis of the implementation of the washing of the land, both in a Christian way or in a traditional view. In fact, both churches and traditional institutions give each other values based on their respective ideological foundations. The church sees washing the country as a theological vehicle for the community by providing new values for the community's traditional practice.

For the church, washing the country is a means of renewing people's lives and restoring the universe's sustainability. Whereas in the traditional view, what is done is an appreciation of the work of the ancestors that they have done throughout the history of the Hukurila community. Therefore, these two institutions agree that the effort to give value to each other is more important for the integrity of society, rather than being constantly in a prolonged ideological conflict.

Although at the beginning of the implementation there were ideological tensions, they could be overcome. One of the factors that make washing the country acceptable to the whole community is that on average those in the state saniri are church administrators (GPM Hukurila Congregation Assembly). This makes communication between the two institutions able to run in synergy and even tends to share programs between the two. The reconciliation between the church elite and the traditional elite positively impacts the community, especially at the ideological level, and does not create confusion in society. Each institution can rationalize it well so that the wider community accepts it. Due to the common perception in the community, since 1986 every December 13-16 was agreed as the time for the implementation of the state wash in Hukurila. The determination of this date is based on the date of implementation at the first time the washing ceremony was held, also based on the community's preparation for the Christmas and New Year celebrations.

The fact that the children of the country of Hukurila have experienced very difficult situations with their nature makes them need a reference. Washing the country is one of the references as protection for the universe, is a product of the culture of the children of the Hukurila country in the reciprocal relationship between the sacred - the profane. Knowledge, beliefs, and cultural values in washing the country are centered on efforts to fulfill the need for the environment which is considered important by the children of the Hukurila country. In washing the land, the sacred is seen as the source of human life. The sacred not only inhabits the celestial environment and reigns over it but also inhabits and rules over the profane, namely the earth and human environments.

Page | 28 
The sacred is in the traditional understanding of the Hukurila community about ancestors as well as in the understanding of Christianity.

The relationship between the sacred and the profane in the tradition of washing the land of the children of the Hukurila country is in the relationship of interpenetration; in the form of a sacred relationship to protect the celestial environment, the earth environment, and the human environment. Environment as The expression of religious beliefs (both ethnic and Christian) is a tangible form of unwritten or written teachings as well as an awareness of the totality of obedient children of the country. The penetration relationship centered on the sacred is a source of harmony that is preserved by the culture of the children of the Hukurila country to be able to face their environment so that they can survive.

The concept of washing the country as a process of interpenetration creates a form of social order and defense of the existence and sustainability of people's lives. The interpenetration relationship in washing the country shows the integrity of ethnic-religious values and Christianity which is getting stronger and stronger in the life movements of the children of the Hukurila country. The integrity of this belief gives meaning to each other, directs the knowledge, values, and actions of the children of the Hukurila country in utilizing the environment according to their needs and not destroying it, in the awareness that its existence must be preserved. This means maintaining the welfare of the children of Hukurila in the long term. The meaning of interpenetration is instilled and maintained in the totality of the lives of the children of the Hukurla country so that it becomes a sacred belief. In other words, the process of interpenetration in washing the country in Hukurila does not weaken each other's values but strengthens them as children of the Hukurila country in the totality of their beliefs.

\subsection{Washing the liver as the value of the interpenetration process}

\subsubsection{Washing the Heart: Cultural Harmony of the Children of the Hkurila Country}

Harmonization as a norm and obligation is not only cultural in nature, meaning that it must be manifested in self-culture and infused as their personality, but culture itself is also a target for harmony in every washing of the country. The cultural harmony that is required for the children of the Hukurila country is the harmony between self-culture and personality. By them, there is no tension between personal behavior and kebatinan, not only on the physical or emotional level but on the children of the Hukurila country as their identity. The value of washing the heart as a form of cultural harmony that requires harmonization among the children of the Hukurila country is perceived by them as an authentic and natural form of expression for the intensity of personality so that the norm spontaneously continues to move in the steps of the children of the Hukurila country. They feel at home and happy in the formation of themselves like this. On the other hand, the identity that is formed is not perceived as wild that must be hidden and imprisoned behind a mask of falsehood. Self-culture is faithfully expressed as completely and completely as possible for the whole personality. The children of the Hukurila country live their harmonization as a historical, social, and cultural bond. Thus they consciously and freely achieve total harmony in the correlation between their own traditions and culture. This cannot be separated from their awareness as a whole community group.

Harmonization of life in the meaning of washing the country is the development of creative children of the Hukurila country. On the one hand, their development as a completely unique society is the product and result of their previous situation. On the other hand, collegial development produces something new and original. This is because in themselves collegially, be it the traditional elite group and the church and society as a whole, lies a dynamic as a source of activity and its own development. All novelties arise from that source, but at the same time, they cultivate the resource effectively to develop and enrich their own source.

The way they pass the values of washing their hearts to the next generation shows the occurrence of a woven and interwoven communication between generations. The old generation (parents) educate their children by communicating the tradition of washing the country as a culture and the value of washing the heart as identity. Although later the new generation brought updates in the tradition of washing the country, this dialogue made the old generation also develop a new meaning for washing the country. This is because the new generation provides a new impulse for the development of the children of the Hukurila country as a whole, but does not create divisions in the generations. Physically, they follow the traditions that have been carried out by previous generations but incorporate new values according to their innovation on the reality they face. In other words, new values increasingly animate and unite all contradictions and increasingly sharp differences.

\subsubsection{Washing the Heart: Christian Style Hukurila Culture}

The Christian style of Culture is a monodical style in the Christians of Hukurila. On the one hand, they still adhere to Christian teachings as enshrined in the Bible, but on the other hand, they do not leave behind their cultural roots which are attachments to their ancestors as embodied in their customs. On the one hand, they believe in the conceptions, allusions to the teachings of religious texts in the scriptures, on the other hand, they are constructed to believe in the imagination of the cognition of the ancestors which was conceptualized in a systematic, philosophical manner and has meaning in reality. This means that their perspective on the religious style of Christian Culture is not only a matter of spirit but there has also been an intense relationship

Page | 29 
between religion as a source of values and customs as cognitive creations of the ancestors. Christian Culture is the result of a compromise dialectic (interpenetration) from the revelation and subjective experience of the children of the Hukurila country. Therefore, Christian Culture is not only a portrait of its great tradition (pure Christianity) through the guidance of sacred texts but also a portrait of its social-religious behavior and experiences that are influenced by local traditions.

The pattern of relations between the church and customs in the washing of hearts in the washing tradition has legalized Christianity which is in contact with the local wisdom culture of Hukurila, even the pattern of the relationship between the two is considered a necessity. However, it is not uncommon for the Christian culture of Culture in Hukurila to get very big opposition from Christian communities of different sects. The Christian style of culture is considered to have played with the purity of Christian teachings and is not worthy of bearing Christianity as its religion. Whereas Christianity, including the Christian culture of culture, is universally a guide that directs and teaches the lives of the children of the Hukurila country to realize and acknowledge who created them, and what they were created for.

The children of the Hukurila country already have their own cultural base in synthesizing differences sharp contrast between adat and the church in a dialectical harmony point. They have proven that Christianity is not just an empty revealed religion without form, but has been internalized into a unique social construction in the reality of their context. This means that the Christian Culture style is not just a religious style but a way of life that is manifested in their self-culture and identity, which is manifested in the harmonious relationship between them and their nature as well as their totality as children of the Hukurila country who live in peace. Therefore, the basic construction of the Christian Culture style is based on the basic values of Christianity and also the traditional values that want to live in peace as fellow human beings as well as with nature. It is the strength of their meaning that has created a distinctive religious style for the children of the Hukurila country, and which has brought together a dynamic and distinctive point of harmony. This social construction is depicted in the concept of washing the country as washing the heart, where fellow Hukurila children join each other in harmony to complete work and in maintain the continuity of past, present, and future life. Therefore, as a ritual, washing the country has the basics of understanding and critical awareness to cultivate and link the knowledge system, belief system, and reality or play in a dialectical process between customs and the church, in order to carry out a practical religious life.

The conceptual framework for washing the heart contextually based on local values has given birth to a new meaning for Christianity, in the form of the Christian Culture of Hukurila. Therefore, the style of Christian Culture is not a syncretism between Christianity and tribal religion which is contained in customary values but is a way of religious life and how to become a good religion in social reality in Hukurila.

On that basis, the religious style of Christian Culture in washing the country has an originality that spans historical space and time. This religious style makes God not only immanent but also transcendent, thus making Hukurila a place where God encounters humanity intensely. This is a masterpiece of Hukurila's children in building their existence as a unique community. They do not only do theology or theorize about Christianity in the scriptures but more than that they want to build an existence of a religious style based on their local context based on the long history of the children of the Hukurila country itself.

The Christian style of culture longs for order between human beings and the universe. Every ritual that is carried out is to maintain a balance between the children of the Hukurila country and nature because the need for humans to survive and who can maintain the continuity of life is nature. So it is not surprising that the cosmos is then worshiped as a sign of God's presence in their lives. The names for God are also the creation of their cognition of the cosmos. The sun, moon, sky, and so on are images of a great and powerful master who can give blessings but also bring curses. He is believed to be the perfect God, protecting, nurturing, and governing. His wrath can make this world fall apart which results in human destruction. Therefore, in the Christian Kultur style, religious customs have their own binding power. Leaving the traditions that have been handed down by the ancestors means threatening the sustainability of the existence of the people. Ancestors are not gods who created the cosmos, but the creators of noble values to maintain the order of the cosmos. Washing the country is an example of a value system created and carried out by the ancestors and requires the next generation to obey these norms.

\subsubsection{Washing the Heart: The Value of Cultural Christian Brotherhood in Hukurila}

The fact that washing the heart is not just a sociological or cultural event, but also a very basic theological event. As a theological event, the violation of that reality is denounced as impertinent and sinful, be it a religious sin or a customary sin. Washing the heart shows the existence of a strong brotherhood, namely building a common life between others and nature which has been accepted and lived as a special blessing for the children of Hukurila country. It shows the values of friendship, a true brotherhood which is the core of the scripture itself. The value of washing the heart in washing the country makes Christianity in Hukurila a way of religion that opens the way to live in peace in their local context. This value is not disbelief towards Christianity but is a religious way of the children of the Hukurila country who realize their religious vocation in their very strong culture. This is because in 
washing their hearts, the Christian style in Hukurila really understands the characteristics of its culture with a number of cultural values that cannot be separated from the identity of the children of Hukurila country.

The value of the philosophy of washing the heart in Hukurila shows that their religious style is unique because it teaches and obliges the children of Hukurila to place, build and raise themselves in the washing tradition of the country. This is, of course, based on a very strong genealogical relationship in Hukurila between them and their ancestors. This fact must be appreciated as a historical achievement and a principle of religious life that must be lived for Christianity in Hukurila. This religious dimension means that the appreciation of Christianity does not only stop at the outward appearance which is formalistic with the texts of the scriptures, but also the deepest essence of Christianity through which the children of the country of Hukurila can achieve their full religious appreciation. That is, this deepest essence strengthens the social, religious, and cultural bases that are intertwined with one another in the face of Christianity in Hukurila.

The strong values of brotherhood as a philosophy of heart washing show that the children of the country of Hukurila have managed their plurality of life in cultural wisdom that is critical, intact, synergistic, and cooperative. The core of the choice is a dialectical togetherness management pattern between Christians and the culture of the children of the Hukurila country. The dialectical linkage in washing the country as washing the heart has surpassed and overcomes the various weaknesses of traditional and church exclusivity. The life highlighted by the children of the Hukurila country is a social configuration that is interrelated both in the structure of culture, kinship, religion as well as in its cognitive structures.

\section{Conclusion}

Traditional rituals that develop in society are not only seen in the physical aspects of the ritual implementation alone. Tra ditional rituals that are carried out always have philosophical backs that were born from the cognitive intelligence of the predecessors (ancestors). Each ritual has a meaning that forms the identity of the children of the country, including washing the country. This tradition revealed so many meanings regarding identity and the deep essence of humanity. Washing the country is considered a sacred tradition because the children of the country of Hukurila still maintain their traditional identity and continue to exist in the changing times.

Washing the country not only teaches about the role of ancestors in the history of the children of the Hukurila country but also sows critical reasoning that highlights the role of humans in nature conservation. Wash the country promotes environmental preservation as part of social piety. Environmentally friendly reasoning is grown by a discourse on nature conservation as a variant of the practice of faith.

This paper re-awakens that the ritual of washing the land has placed nature for humans in a sacred position, and has become the center point of the totality of human life so that nature becomes God for humans who are worshiped. Humans do not dare to treat nature arbitrarily because it is an entity that must be worshiped. Thus, as an act of theology, washing the country "forbids" destructive attitudes and recognizes the importance of maintaining and preserving the community environment.

Washing the country is not only a tradition that continues to be repeated every year, without any depth of meaning. The content of values that continue to grow in washing the country, illustrates the creation of cognition of the children of the Hukurila country resulting from their empirical experiences that are never final. This is because adat ideas continue to have a dialectic with gospel ideas in their reality. Just as the children of the Hukurila country acted and worked in history, so the narratives in the Bible testify to God acting and working in history.

Funding: This research received no external funding.

Acknowledgments: The writers acknowledge the editors and the anonymous reviewers for the contribution of this paper. The writers also acknowledge Universitas Katolik Santo Thomas, Indonesia as the source of data that was focused on Christianity values and Tribal religion in Indonesia's culture.

Conflicts of Interest: The authors declare no conflict of interest. 


\section{References}

[1] Bakker, A. (1995). Cosmology and Ecology: Philosophy of the Cosmos as a Human Household. Yogyakarta: Canisius.

[2] Bevans, S. B. (2010). Theology in a Global Perspective. Flores: Ledalero.

[3] Cathrin, S. (2017). Review of Cultural Philosophy of Village Clean Up Ceremony in Tawun Village, Kasreman District, Ngawi Regency. East Java: Faculty of Philosophy, Gadjah Mada University.

[4] Drewes, B. F. \& Julianus, M. (2003). What is Theology: An Introduction to Theology. Jakarta: BPK Gunung Mulia.

[5] Gaspersz, S. (2003). Church and Customs: Reflections of an Ambonese, Paper presented at the Convent of Pastors of the Maluku Indjili Church on 5-6 November 2003 at the Hotel "de Wormshoef" Dorpstraat 1926741 AS Lunteren (Netherlands).

[6] I Ngurah, S. (2017). Birth of the Happy Age: Transformation of Indigenous Theology in Papua. Semarang: Walisongo State Islamic University.

[7] Indraningsih I.. (2011). Paul Ricoeur's Hermeneutics and Its Application to the Meaning of Symbols in the Romance "Rafilus". East Java: Faculty of Philosophy, Gadjah Mada University.

[8] Jelahu, T. T. (2016). Conceptualization Ideas for Translation Models in Strengthening the Catechetical Community, Sepakat Journal, 2(2), 3442.

[9] Malau W., \& William C.G. (2016). The Role of the Batak Karo Protestant Church in Maintaining and Preserving the Karo Ethnic Culture in Kabanjahe. Anthropos: Journal of Social and Cultural Anthropology, 2 (2), 54-65.

[10] Manyaran. (2015). In Sociality, Scientific Journal of Sociology-Anthrophology, 5(2), 78-84.

[11] Maytisa, Dara. (2015). Tayuban and the Clean Village Tradition in Wonogiri (Qualitative Descriptive Study on the Sambeng Hamlet Community, Kepuhsari Village, Sub-District. East Java : Hassanuddin.

[12] Muslim, A. (2013). Religious Articulation of Basudara Poems in Maluku. Banten : University of Sultan Maulana Hasanuddin.

[13] Naya, A., M., \& Solissa, I. (2016). Pataniti Ritual (Study of Community Culture in the Leihitu Peninsula, Central Maluku Regency). Ambon : Fikratuna.

[14] Rey, K. T. (2018). Theological Construction in the Context of Repositioning the Thoughts of Church Members. Surakarta: Torsina College of Theology.

[15] Saidi, A. C. (2008). Hermeneutics: A Way to Understand Texts in the Journal of Sosiotechnology. Bandung: Institute of Technology.

[16] Simon, J. C. (2018). Paul Ricoeur's Contribution to the Theological Process, in the Journal of Theological Echoes. Duta Wacana Christian University: Yogyakarta

[17] Watloly, A. (2005). New Maluku: The Rise of the State Child Existence Machine. Yogyakarta: Kanisius. 